\title{
INTERNATIONAL LAW AND THE UNITED STATES ROLE IN THE VIET NAM WAR
}

\author{
RICHARD A. FALK*
}

I

No contemporary problem of world order is more troublesome for an international lawyer than the analysis of the international law of "internal war."1 A war is usefully classified as internal when violence takes place primarily within a single political entity, regardless of foreign support for the contending factions. ${ }^{2}$ The insurgents who won the American Revolution were heavily supported by French arms. Wars of national liberation are not new, nor is external support for an incumbent regime. But considerable historical experience with foreign intervention in internal wars has not been adequately incorporated into prevailing doctrines of international law. In an age of civil turbulence and nuclear risk, the requirements of world order make imperative the effort to overcome the consequent confusion. ${ }^{3}$

The central issue is whether an externally abetted internal war belongs in either traditional legal category of war- "civil" or "international." Four sub-inquiries are relevant. What are the legal restraints, if any, upon national discretion to treat a particular internal war as an international war? What rules and procedures are available to determine whether foreign participation in an internal war constitutes "military assistance," "intervention," "aggression," or "an armed at-

- Milbank Professor of International Law, Woodrow Wilson School of Public and International Affairs, Faculty Associate, Center of International Studics, Princeton University; B.S. 1952, Univ. of Pennsylvania; LL.B. 1955, Yale University.

1. See generally Internal War (Eckstein ed. 1964); INTERnational Aspects of CiviL STRIFE (Rosenau ed. 1964) [hereinafter cited as RosenAu].

2. The "internalness" of an internal war is a consequence of the objectives and arena of the violence. There are, of course, a range of different types of internal war. Sce Rosenau, Internal War as an International Event, in RoseNAu 45, at 63.64. Rosenau uscfully differentiates between internal wars, in terms of whether they are fought primarily to achieve changes in the personnel of the leadership, the nature of political authority, or the socio-political structure of the society.

3. For helpful exposition see Huntington, Patterns of Violence in World Politics, in Changing Patterns of Military Politics 17 (Huntington ed. 1962); sce also Bloompifiv, International Military Forces $24-46$ (1964). See the table classifying examples of internal war in terms of "basically internal," "externally abetted internal instability," and "externally created or controlled internal instability." $I d$. at 28-30. Incidentally, Professor Bloomfield located the war in Viet Nam in the middle category as of 1964. 
tack"? What responses are permissible by the victim of "aggression" or "an armed attack"? Finally, what should be the roles of national, regional, and global actors in interpreting and applying the relevant rules?

If the internal war is regarded as a "civil" war, then the legally permitted response to intervention is restricted to counter-intervention; ${ }^{4}$ an intervening nation whose own territory is not the scene of conflict may not attack the territory of a state intervening on the other side..$^{5}$ If foreign intervention were held to convert an "internal" war into an "international" war, the intervention could be regarded as an armed attack that would justify action in self-defense proportionate to the aggression. The victim of aggression is entitled, if necessary, to attack the territory of the aggressor, expanding the arena of violence to more than a single political entity. ${ }^{\circ}$ Given the commitment of international law to limiting the scope, duration, and intensity of warfare, it would appear desirable severely to restrict or perhaps to deny altogether, the discretion of nations to convert an internal war into an international war by characterizing external participation as "aggression" rather than as "intervention."?

The American outlook on these issues has dramatically changed in recent years. John Foster Dulles is properly associated with the expansion of American undertakings to defend foreign nations everywhere against Communist takeovers by either direct or indirect aggression. But even Dulles did not propose treating indirect aggression as the equivalent of an armed attack by one country on another. In fact, during the Congressional hearings on the Eisenhower Doctrine in $1957^{8}$

4. I have developed this position in a paper given at the 1966 Annual Meeting of the American Society of International Law under the title The International Regulation of Internal Violence in the Developing Countries, to be published in 1965 Proc. As. Soc. INT'L L.

5. The assertion in the text must be qualified to the extent that the United States decision to bomb North Viet Nam is treated as a law-creating precedent (rather than as a violation).

6. If the conceptions of "aggression" and "armed attack" are so vague that nations can themselves determine their content, a self-serving legal description of the desired course of state action can be given and is not subject to criticism in a strict sense. A critic would be required to stress that an expansive definition of "armed attack," although not forbidden by prior rules of law, was an unwise legal claim because of its status as a precedent available to others and because of its tendency to expand tho scope and magnify the scale of a particular conflict.

7. It is important to distinguish between the factual processes of cocrcion and the legal labels used to justify or protest various positions taken by the participants. Aggression is a legal conclusion about the nature of a particular pattern of coercion.

8. The critical section in The Eisenhower Doctrine (1957) is Section 2: 
Dulles declared "... if you open the door to saying that any country which feels it is being threatened by subversive activities in another country is free to use armed force against that country, you are opening the door to a series of wars over the world, and I am confident that it would lead to a third world war."' In my judgment, by bombing North Viet Nam the United States is opening such a door and is setting a dramatic precedent of precisely the sort that Dulles had in mind. Our pride as a nation is now so deeply dependent upon a successful outcome in Viet Nam that our Government seems insufficiently sensitive to the serious negative consequences of the Viet Nam precedent for the future of world order. ${ }^{10}$

The appraisal of a claim by a national government that an act of intervention is "aggression" is a complex task even if performed with utter impartiality. It depends on assessing very confused facts as to the extent and phasing of external participation, as well as upon interpreting the intentions of the participating nations. For instance, one must distinguish in the behavior of an international rival between a program of unlimited expansion through violence and intervention to assure the fair play of political forces in a particular domestic society. In the context of contemporary international politics, a crucial assessment is whether Communism or specific Communist states propose unlimited expansion by using unlawful force or whether they rely upon persuasion and permissible levels of coercion. ${ }^{11}$ It is difficult to obtain adequate evidence on the limits of permissible political and para-military coercion. ${ }^{12}$ Arguably, even a program of maximum ex-

The President is authorized to undertake, in the general area of the Middlc East, military assistance programs with any nation or group of nations of that area desiring such assistance. Furthermore, the United States regards as vital to the national interest and world peace the preservation of the independence and integrity of the nations of the Middle East. To this end, if the President determines the necessity thercof, the United States is prepared to use armed force to assist any such nation or group of nations requesting assistance against armed aggression from any country controlled by international communism: Provided, That such employment shall be consonant with the treaty obligations of the United States and with the Constitution of the United States.

36 DEP'T STATe Bull. 481 (195\%).

9. The President's Proposal on the Middle East, Hearings before Senate Committees on Foreign Relations and Armed Services, 85th Cong., 1st Sess., pt. 1, at 28 (1957).

10. The role of national claims of a unilateral nature in the development of inter. national law is examined in Falk, Toward a Responsible Procedure for the National Assertion of Protested Claims to Use Space, in SPAcE AND SOcietY 91 (Taubenfeld ed. 1964).

11. This is the main theme of a speech by the Secretary of State. Sec Rusk, Address, 1965 Proc. AM. Soc. INT'L L. 247, 249-51.

12. I have discussed these issues in Falk, On Minimizing the Use of Nuclear Weapons: 
pansion should be countered by self-limiting responses aimed at neutralizing Communist influence on internal wars and at building a world order that minimizes the role of military force. ${ }^{13}$ The must also not overlook the welfare of the society torn by internal war. The great powers tend to wage their struggles for global dominance largely at the expense of the ex-colonial peoples. ${ }^{14}$ These considerations support a conservative approach to internal wars, an approach treating them as civil wars, and permitting a neutralizing response as a maximum counteraction. And, specifically, if efforts to neutralize Communist expan$\operatorname{sion}^{15}$ in Viet Nam can be justified at all, the appropriate role of the United States is to counter "intervention" rather than to respond to an "armed attack."

The issue of self-determination is also relevant in the setting of internal war. If Communists or Communist-oriented elites can obtain political control without significant external support, it becomes difficult to vindicate Western intervention in terms of neutralizing Communist expansion. Castro's revolution represents a Communist success that was achieved without significant external support until after political control of Cuba was fully established. Part of the objection to American intervention in the Dominican Republic in 1965 arises from the absence of prior foreign intervention. The policies of preventing war, minimizing violence, and localizing conflict seem in these contexts to outweigh the objectives of anti-Communism; the United States serves both its own interests and those of the world community by respecting the outcome of internal political struggles. Unless we respect domestic political autonomy, our adversaries have no incentive to refrain from participating on the side of their faction. The primary objective in relation to

A Comparison of Revolutionary and Reformist Perspectives, in FALs, Tucher, \& Younc,

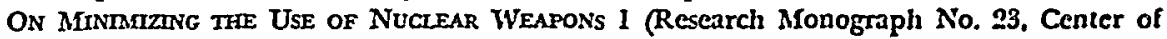
International Studies, Princeton University, March 1, 1960).

13. Everyone would agree in the abstract that it is important to reconcile policies directed at limiting the expansion of adversaries with those aimed at avoiding warfare, particularly nuciear warfare. See FALK, LAW, MORALTTY, AND WAR 32-65 (1963).

14. Relative peace is obtained through mutual deterrence at "the center" of the inter. national system. Struggles for expansion are confined to "the periphery" where the risks of nuclear war can be minimized and where the costs of conflict an be shilted from the great powers to the ex-colonial nations.

15. My own judgment, based on the analysis of the Geneva settlement in 1954, is that the war in South Viet Nam represents more an American attempt at "rollbacls" chan a Communist attempt at "expansion." The Geneva Conference looked toward the reunification of the whole of Viet Nam under the leadership of Ho Chi Minh. The introduction into South Viet Nam of an American military presence thus appears as an effort to reverse these expectations and to deny Hanoi the full extent of its victory against the French. Cf. also Lacouture, Vietnam: Between Two Truces 17-68 (1966) [hereinafter cited as LACOUTURE]. 
internal warfare is to establish rules of the game that allow domestic processes of political conflict to proceed without creating undue risks of a major war. In addition, human welfare and democratic ideals are best served by allowing the struggle between Communist and Western approaches to development to be waged by domestic factions. Recent events in Indonesia, Algeria, and Ghana demonstrate that these internal struggles for ascendancy are not inevitably won by Communists.

Civil strife can be analyzed in terms of three different types of violent conflict. ${ }^{16}$ A Type I conflict involves the direct and massive use of military force by one political entity across a frontier of anotherKorea, or Suez. ${ }^{17}$ To neutralize the invasion it may be necessary to act promptly and unilaterally, and it is appropriate either to use force in self-defense or to organize collective action under the auspices of a regional or global institution. A Type II conflict involves substantial military participation by one or more foreign nations in an internal struggle for control, e.g., the Spanish Civil War. To neutralize this use of military power it may be necessary, and it is appropriate, to take offsetting military action confined to the internal arena, although only after seeking unsuccessful recourse to available procedures for peaceful settlement and machinery for collective security. A third type of conflict, Type III, is an internal struggle for control of a national society, the outcome of which is virtually independent of external participation. Of course, the outcome of a Type III conflict may affect the relative power of many other countries. Hungary prior to Soviet intervention, Cuba (1958-59), and the Dominican Republic prior to United States intervention, typify this class of struggle. It is inappropriate for a foreign nation to use military power to influence the outcome. The degree of inappropriateness will vary with the extent and duration of the military power used, and also with the explicitness of the foreign nation's role. ${ }^{18}$ Thus, the reliance on Cuban exiles to carry out the antiCastro mission at the Bay of Pigs (1961) is somewhat less inappropriate

16. These "types" are analytical tather than empirical in character. In actual cxperl. ence a particular occasion of violence is a mixture of types, although the nature of the mixture is what makes one classification more appropriate than another.

17. Border disputes generating limited, but overt, violence by one entity against an. other are a special sub-type under Type I that may or may not support a finding of "armed attack" or a defensive claim of "self-defense."

18. See the emphasis on the covertness of the United States role in sponsoring the Bay of pigs invasion of 1961 as an influential factor in the decision to proceed in Scillesinomn, Jr., A Thousand Days $238-97$ (1965). And note that Schlesinger's opposition to the invasion was based in large part on his belief that it would be impossible to disguise the United States' role. $I d$. at $253-54$. 
than the use of United States Marines. Perhaps appreciating this distinction, North Viet Nam relied almost exclusively on South Vietnamese exiles during the early years of the anti-Diem war..$^{10}$

These three models are analytical tools designed to clarify the nature and consequences of policy choices. Reasonable men may disagree on the proper classification of a particular war, especially if they cannot agree on the facts. An understanding of the controversy over the legality of United States participation in the war in Viet Nam seems aided by keeping in mind these distinct models.

The United States is treating the war as a Type I conflict. I would argue, for reasons set out in the next section, that the war belongs in Class III. But if this position entailing non-participation is rejected, then the maximum American response is counter-intervention as is permissible in a Type II situation.

Two general issues bear on an interpretation of the rights and duties of states in regard to internal wars of either Type II or III. First, to what extent does the constituted elite-the incumbent regime-enjoy a privileged position to request outside help in suppressing internal challenges directed at its control ${ }^{20}$ Traditional international law permits military assistance to the incumbent regime during early stages of an internal challenge. However, once the challenging faction demonstrates its capacity to gain control and administer a substantial portion of the society, most authorities hold that a duty of neutrality or non-discrimination governs the relations of both factions to outside states. ${ }^{21} \mathrm{~A}$ state may act in favor of the incumbent to neutralize a Type III conflict only until the challenge is validated as substantial. A crucial question is whether outside states can themselves determine the point at which the challenge is validated, or whether validation is controlled, or at least influenced, by international procedures and by objective criteria of validation. The United States legal position stresses its continuing right to discriminate in favor of the incumbent regime and to deny even the political existence of the National Liberation Front (N.L.F.), despite

19. See, e.g., WARNER, The LAST Confuctan 155 (1963) [hereinafter cited as WArNer]; Fall, ThE Two VIEt-Nans 316-84 (rev. ed. 1964) [hercinafter cited as TuE Two VIET. NAMS].

20. See, e.g., Garner, Questions of International Law in the Spanish Civil War, 31 As. J. INT'L L. 66 (1937).

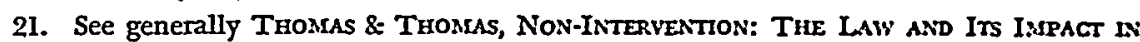
THE AMERICAS 215-21 (1956); see also LAUTERPACHT, RECOCNITION IN INTERNATIONAL LAW 199-201, 227-33 (1957); Falk, Janus Tormented: The International Law of Internal War, in Rosenau 185, 197-209. 
the de facto existence of the N.L.F. over a long period and its effective control of a large portion of the disputed territory. ${ }^{22}$

A second question partially applicable to Viet Nam is whether it is ever permissible to discriminate in favor of the counter-elite. The Communist states and the ex-colonial states of Asia and Africa assume that there are occasions warranting external participation in support of the insurgent faction. The Afro-Asian states argue that political legitimacy is established by an international consensus expressed through the formal acts of international institutions, rather than by the mere control of the constituted government. ${ }^{23}$ This theory of legitimacy sanctions foreign military assistance to an "anti-colonialist" struggle. The extent to which this new attitude alters traditional international law is at present unclear, as is its full relevance to the conflict in Viet Nam. The argument for applicability to Viet Nam would emphasize the continuity between the 1946-54 anti-colonial war in Viet Nam and the present conflict. It would presuppose that the diplomatic recognition of South Viet Nam by some sixty countries conferred only nominal sovereignty, and that the Saigon regime is a client government of the United States, which has succeeded to the imperialistic role of the French. This approach implies that external states such as North Viet Nam, China, and the Soviet Union have "the right" to render support to the N.L.F.

These notions of permissible discrimination in favor of the constituted elite or the challenging counter-elite complicate considerably the legal analysis of participation in a Type III conflict and blur the boundaries between Types II and III. Any adequate statement of the international law of internal war, must acknowledge this complexity, and admit along with it a certain degree of legal indeterminancy. ${ }^{24}$

II

The vast and competent literature on the war in South Viet Nam provides an essential factual background for an impartial approach to

22. For a description of the extent of the N.L.F.'s governmental control sce BURcietr, VIETNAM: INSLE STORx OF The Guerilla WAR 223-26 (1965); for legal argument sce LAUTERPACHT, op. cit. supra at 175-238.

23. The legal status of a counter-elite in a colony is certainly improved by the repeated condemnations of colonialism in the United Nations and the recent passage of formal resolutions calling for decolonialization. Factors other than claims to be the constituted government are regularly taken into account in assessing claims of legitimacy in international relations.

24. For the theoretical background on legal indeterminacy in international law sce Lauterpacht, Some Observations on the Prohibition of 'Non Liquet' and the Complete. ness of the Law, in SyMbolaE VerzIJL 196-221 (1958); Stone, Non liquet and the Function of Law in the International Community, 35 BRrr. YB. INr'L L. 124 (1959). 
the legal issues presented in the Memorandum of Law prepared by the State Department. ${ }^{25}$ It is impossible to summarize all of the relevant facts, but it may be useful to indicate certain lines of reasoning that account for part of my disagreement with the official legal analysis. This disagreement reflects my interpretation of the internal war as primarily a consequence of indigenous forces. Even more, it stems from my concern for taking into account certain facts entirely excluded from the Memorandum, such as the pre-1954 war against the French and the repression of political opposition by the Diem regime.

It must be kept in mind that the present conflict in Viet Nam originated in the war fought between the French and the Vietminh for control of the whole of Viet Nam, which was "settled" at Geneva in $1954 .{ }^{26}$ Although the intentions of the participants at Geneva were somewhat ambiguous, the general view at the time was that the Geneva agreements anticipated reunification under the leadership of $\mathrm{Ho}$ Chi Minh by 1956 to coincide with the French departure. France came to Geneva a defeated nation; the Vietminh held two-thirds or more of the country. ${ }^{27} \mathrm{Had}$ elections been held, it is generally agreed that reunification under Ho Chi Minh would have resulted, however one interprets the suppression of political opposition in the North or intimidation in the South. ${ }^{28}$ Independent observers also agree that the anticipation of the prospect of peaceful reunification led Hanoi to observe the Geneva arrangements during the two years immediately following 1954. The undoubted disappointment caused by the refusal of the French and the Americans to make Saigon go through with the elections helps explain the resumption of insurrectionary violence after 1956.20

25. Among those most helpful see Iacouture; THE Two VIET-Nasis; FalL, Vietiase WItNEss 1953-66 (1966) [hereinafter cited as Vietnasr WITNEss]; SHApLEN, Tue Lost RevoLUtIon (rev. ed. 1966) [hereinafter cited as ShapLen]; LANCister, TuE ENaNcipation of FrENCH INDO-ChINA (1961) [hereinafter cited as LANCASTER]; WARNER.

26. The settlement was not very realistic. It failed to take into account Saigon's $\infty$ clusion or the American opposition to the Geneva solution. No responsibility was imposed upon the French to assure compliance with the terms of settlement prior to their withdrawal. See WARNER 142-43.

27. For a general account see LANCASTER 290-358; VIETNAM WITNESS 69-83; for the fullest account of the Geneva negotiations see LACOUTURE \& Devillers, LA FIN D'UNE CuERRE (1960). And see Eisenhower, Mandate for Chance 332-75 (1963) for official American thinking during this period.

28. There is agreement that an election held within the prescribed period would have been won by Ho Chi Minh. See, e.g., Shaplen xi, Warner 142-49; Lncouture 32: "The final declaration of the Geneva Conference foresaw, of course, that general election vould permit the reunification of Veitnam two years later. And none doubted at the time that this would be to the benefit of the North."

29. See LACOUtuRE 32-50. 
The Vietminh did leave a cadre of 5,000 or so elite guerrillas in the South, withdrawing others, as agreed, north of the Seventeenth Parallel. ${ }^{30}$ Those left in the South apparently went "underground," hiding weapons for possible future use. This action seems no more than a reasonable precaution on the part of Hanoi in light of Saigon's continuing objection to the Geneva terms, and in view of Washington's evident willingness from 1954 onward to give Saigon political and military support. Given the terms of conflict and the balance of forces in Viet Nam prior to the Geneva Conference, French acceptance of a Viet Nam-wide defeat, American reluctance to affirm the results of Geneva, and Saigon's repudiation of the settlement, it seems quite reasonable for Hanoi to regard a resumption of the civil war as a distinct contingency. Although a decade of de facto independence (affirmed by diplomatic recognition) now gives South Viet Nam a strong claim to existence as a political entity, Hanoi certainly had no obligation in 1954 to respect claims of an independent political status for Saigon. ${ }^{31}$ To clarify the diplomatic context in Geneva, it is well to recall that the Vietminh was the sole negotiator on behalf of Vietnamese interests at Geneva in 1954.

Later in 1954 the Saigon regime under Premier Diem ruthlessly sup. pressed all political opposition. ${ }^{32}$ Observers agree that organization of an underground was an inevitable reaction to this suppression, and that the N.L.F. at its inception included many non-Communist elements. ${ }^{35}$ It also appears that Saigon was unwilling to negotiate, or even consult, on questions affecting reunification, and was unwilling to normalize economic relations with Hanoi. The great economic strain imposed on North Viet Nam forced it to use scarce foreign exchange to obtain part of its food supply from other countries. ${ }^{34}$

Furthermore, the French military presence soon was replaced by an American military presence prior to the scheduled elections on reunification. ${ }^{35}$ The evolution of an American "commitment" to Saigon's

30. Id. at 32-68; cf. Vietnam WrTness 169-89.

31. Fanoi was "entitled" to prevent Saigon from establishing itself as a political entity with independent claims to diplomatic status as a sovereign state. A separation of Viet Nam into two states was not contemplated by the participants at Geneva.

32. See WARNER 107-24; LACOUTURE 17-31.

33. Fall, Viet-Cong-The Unseen Enemy in Viet-Nam, in THE VIET-NAM READER (Raskin \& Fall eds. 1965) [hereinafter cited as VIET-NAM READER].

34. LACOUTURE 34-35, 68.

35. This is the major thesis of Lacouture, Vietnam: The Lessons of War, reprinted from the New York Reveiw of Books, March 3, 1966, p. 1, in Hearings on S.2793 Before the Senate Committee on Foreign Relations, 89th Cong., 2d Sess. 655-61 (1966) [hereinafter cited as VietNam HEARINGs]. 
permanence and legitimacy contrasts radically with both the expectations created at Geneva in 1954 and the subsequent attitudes of the French. United States involvement in the politics of South Viet Nam increased constantly; it was no secret that the Diem government largely was constituted and sustained in its early months by the United States. ${ }^{30}$

Despite the escalating American political, military, and economic assistance, the Saigon regime proved incapable of achieving political stability. Numerous regimes have come and gone. None has commanded the respect and allegiance of any significant segment of the population. Often in situations of civil war diverse factions are able to establish an expedient working unity during the period of common national emergency. The N.L.F. seems to maintain substantial control over its heterogeneous followers while one Saigon regime after another collapses or totters on the brink. The United States recognized at an early stage that the Saigon regime had to transform its own feudal social structure before it could provide the basis for viable government in South Viet Nam. ${ }^{37}$ This is a most unusual demand by an external ally; it bears witness to the fragile and dubious claim of each successive Saigon regime to govern even the parts of South Viet Nam not held by the Vietcong.

In addition, Saigon and the United States seem to have neglected repeated opportunities for negotiations with Hanoi during earlier stages of the war. ${ }^{38}$ As late as February, 1965, the United States government rebuked $U$ Thant for engaging in unauthorized negotiations. Until the prospects for a military solution favorable to Saigon diminished to the vanishing point, the United States made no attempt to negotiate a peaceful settlement or to entrust responsibility for settlement to either the Security Council or the Co.Chairmen of the Geneva

36. For an account of the covert dimension of the United States role in the domestic affairs of South Viet Nam see WISE \& Ross, THE INvisible Governarent 155-64 (1964). There are also references to the exercise of covert influence by the United States in LAcoutuns, SHAPLEN, and WARNER, American strategies of covert influence in forcign countries are analyzed and described in Blackstock, The Strategy of SUbversion (1964).

37. Cf. Ietter of President Eisenhower to Premier Diem on October 23, 1954, SEniate Commitiee on Foreign Relations, 89th Cong., 1St Sess., Background Information RELating to Southeast Asia and Vietnass (Comm. Print 1965) [hereinafter cited as BactGROUND INFORMation]. For a recent reiteration, see U.S. and South Vielnamese Leaders Meet at Honolulu, 54 DEP'T STATE BurI. 302-07 (Feb. 28, 1966).

38. The American approach to a negotiated settlement is recounted and criticized in american friends Service Comimittee, Peace in Viet Nasr 50.67 (1965). Among other observations, this report points out that "a careful reading of the New York Times shows that the United States has rejected no fewer than seven efforts to negotiate an end to the war." Id. at 51. See also the article by Flora Lewis, in VIETnam HeAruncs, 323-34. 
Conference. ${ }^{30}$ This reluctance, when added to the political losses suffered by Hanoi at Geneva in 1954, makes it easier to comprehend Hanoi's reluctance to negotiate now. ${ }^{40}$

All of these considerations lead me to regard the war in South Vietnam primarily as a Type III conflict, in which the United States ought not to have participated. Because of Hanoi's increasing participation on behalf of the Vietcong, it is arguable, although rather unpersuasive, that this war is properly categorized as an example of Type II, so that the United States could legitimately give military assistance to Saigon, but is obligated to limit the arena of violence to the territory of South Viet Nam. The weakness of the Saigon regime compared to the N.L.F. renders necessary a disproportionately large military commitment by the United States to neutralize the indigenous advantages of the Vietcong and the support of Hanoi.41 Our disproportionate commitment makes it appear that the United States rather than Hanoi is escalating the war. And this appearance undercuts any defense of our participation as necessary to offset participation on the other side, and thereby

39. For predictions of an American victory in South Viet Nam, sec Raskin \&e Fall, Chronology of Events in Viet-Nam and Southeast Asia, BACKGround INFORMation 377, 388-89, 390-92. As late as October 2, 1963, Secretary McNamara and General Taylor issued an official statement reporting their conclusion that "the major part of the United States military task can be completed by the end of 1965"; and on November 1, 1968 Gencral Paul D. Harkins, U.S. military commander wrote in Stars \& Stripes (Tokyo) that "Victory in the sense it would apply to this kind of war is just months away and the reduction of American advisers can begin any time now." The point of quoting these statements is to suggest that as long as a favorable military solution seemed forthcoming at a tolcrable cost the United States was not interested in a negotiated settlement.

40. An important element in the background of Vietnamese history was the successful resistance movement led by $\mathrm{Ho} \mathrm{Chi}$ Minh against the Japanese in the closing years of World War II. When the Japanese left French Indo-China, Ho Chi Minh was in control of the entire territory, and was induced to accept the return to power of the French colonial administration in exchange for promises of political independence that were never fulfilled. The recollection of this first phase of the Vietnamese war, when added to the post-1954 experience may deepen Hanoi's impression that its political success depends upon military effort. On negotiating with Hanoi, see also the REPORT of THE AD Hoc Congressional Conference on Vietnam, 89Th Cong., 2D Sess. 4-5 (Comm. Print 1966) [hereinafter cited as Ad Hoc Congressional, Conference].

41. Bernard Fall, writing on the sort of military superiority that is required to achieve victory over an insurgency, says:

... in the past it [victory] has required a ratio of pacification forces versus insurgents that is simply not available in Viet-Nam today [Jan. 1965]. In Malaya, British and Malayan forces have achieved a ratio of 50 to 1; in Cyprus, British forces had achicved a 110 to 1 ratio, and in Algeria the French had reached 10 to 1 . The present ratio in South Viet-Nam is 4.5 to 1 , and the French ratio in the First Indochina War was an incredibly low 1.2 to 1 , which (all other matters being equal) would suffice to explain France's ultimate defeat.

VIET-NAM WITNESS 291. 
give "the true" balance of domestic forces a chance to control the outcome. ${ }^{42}$ The State Department Memorandum assumes that the war is a Type I conflict, and argues that American participation is really collective self-defense in response to an armed attack by North Viet Nam upon South Viet Nam. But to characterize North Viet Nam's participation in the struggle in the South as "an armed attack" is unwise as well as incorrect. Such a contention, if accepted as an authoritative precedent, goes a long way toward abolishing the distinction between international and civil war. The war in South Viet Nam should be viewed as primarily between factions contending for control of the southern zone, whether or not the zone is considered a nation. ${ }^{43} \mathrm{~A}$ claim of self-defense by Saigon seems misplaced, and the exercise of rights of self-defense by committing violent acts against the territory of North Viet Nam tends toward the establishment of an unfortunate precedent. $^{44}$

The Memorandum of the State Department was submitted by the Legal Adviser to the Senate Committee on Foreign Relations on March 8, 1966..$^{45}$ In assessing it, we should keep in mind several considerations. First, the United States Government is the client of the Legal Adviser, and the Memorandum, as is entirely appropriate, is an adversary document. A legal adviser in Hanoi could prepare a comparable document. Adversary discourse in legal analysis should be sharply distinguished from an impartial determination of the merits of opposed positions. ${ }^{\text {if }}$

42. Official United States Government statements frequently imply that the United States must render help to the Saigon regime equivalent to the help given by Hanoi to the N.L.F. If "equivalent" is measured by the needs of the ratio, then it may be as much as 110 times as great as the aid given to the insurgents, whereas if equivalent means arithmetically equal, it will be completely ineffectual.

43. Hanoi itself takes a conflict-confining position that the war in Viet Nam is a civil war being waged to determine control of South Viet Nam rather than a civil or international war to determine control of the whole of Viet Nam. Sec, e.g., Poligy Declaration of Premier Pham Van Dong of North Diet-Nam, April 14, 1965, in Viet-Nasr REAden. 342-43 ("Hanoi's Four Points"). See also Program of the National Liberation Front of South Viet-Nam, id. at 216-21 (on Dec. 20, 1960).

44. But, as of July 1966, the United States has not attacked North Victnamese centers of population and has made only limited attacks on industrial complexes (oil depots). The unjustified claim of self-defense has been noted, but it is well to appreciate the as yet restrained form of the claim.

45. An earlier, somewhat skimpy, memorandum, The Legal Basis for US. Actions against North Vietnam, was issued by the Department of State on March 8, 1965; for the text see BACKGROUND INFORMATION 191-94.

46. I have tried to urge a non-adversary role for the international lawyer on several ocasions: see Falk, The Adequacy of Contemporary Theories of International Lazi- 
Second, the Legal Memorandum was evidently framed as a response to the Memorandum of Law prepared by the Lawyers Committee on American Policy Toward Viet Nam. ${ }^{47}$ The argument of the Lawyers Committee fails to raise sharply the crucial issue-namely, the discretion of the United States to delimit its legal rights and duties by treating the conflict in South Viet Nam as an international war of aggression rather than as a civil war. ${ }^{48}$

Third, the Legal Adviser's Memorandum implies that both the facts of aggression and the legal rules governing self-defense are clear. This is misleading. Except in instances of overt, massive aggression across an international frontier, international law offers very indefinite guidance about the permissible occasions for or extent of recourse to force in self-defense. Doctrinal ambiguity is greatest with respect to internal wars with significant external participation. ${ }^{40}$ International law offers very little authoritative guidance on the central issue of permissible assistance to the contending factions. ${ }^{50}$ To conclude that international law is indefinite is not to suggest that it is irrelevant. On the contrary, if rules are indefinite and procedures for their interpretation unavailable, prevailing national practice sets precedents for the future. In this light, American activity in Viet Nam is particularly unfortunate for the future of doctrines aimed at limiting international violence. ${ }^{.1}$

Gaps in Legal Thinking, 50 VA. L. REv. 231, 233-43 (1964); and a recent paper delivered at the Harris Conference on New Approaches to International Relations, at the University of Chicago, June 1966, with the title, New Approaches to the Study of International Law 3-9 (paper available in mimeographed form, to be published subsequently in con. ference volume).

47. See Lawyers Committee on American Policy Toward Vietnam, American Policy Vis-d-Vis Vietnam, Memorandum of Law, in VietnaM Henangs 687-713.

48. The Spanish Civil War is a useful historical precedent for the legal treatment of large-scale foreign interventions on both sides of an internal war. For a full analysis see Padelford, International Law and Diplomacy in the Spanish Civil. Strufe (1989). Another way of posing the issue would be to ask whether Cuba, after the Bay of Plgs invasion, might have been entitled to ask the Soviet Union for military assistance, including air strikes against staging areas in the United States. For a critical account of the lcgal status of American participation in the Bay of Pigs invasion see Falk, American Interven. tion in Cuba and the Rule of Law, 22 OHIO Sr. L.J. 546 (1961).

49. I have argued to this effect, in Rosenau 210-40.

50. By "authoritative guidance" I mean guidance of action by clear, applicable rulcs of international law that are congruent with community expectations about permissible behavior; the rules must be clear enough to permit identification of a violation without independent fact-finding procedures.

51. International customary law evolves as a consequence of national claims and counter-claims acquiring through time an authoritative status. States assert these claims and counter-claims to maximize policy considerations in various contexts. For a major exposition of this process see McDougal \& Burke, The Public Order of the Oceans (1962). 
In this section I propose to criticize the legal argument of the Memorandum, taking some issue with both inferences of fact and conclusions of law. I will analyze the consequences of characterizing international participation in Viet Nam as intervention and counter-intervention in an ongoing civil war. Although I will call attention to the shortcomings in the legal position of the United States, my main intention is to approach this inquiry in the spirit of scholarly detachment rather than as an adversary critic.52 Such detachment is not value-free. I try to appraise the claims of national actors in light of the requirements of world order. My appraisal presupposes the desirability of narrowing the discretion of nations to determine for themselves the occasions on which violence is permissible or that an increase of the scale and scope of ongoing violence is appropriate. I am convinced that it is important for any country (including my own) to reconcile its foreign policy with the rules regulating the use of force in international affairs, and that, therefore, it does not serve even the national interest to accept a legal justification for our own recourse to violence that we would not be prepared to have invoked against us by other states similarly situated. ${ }^{3}$ The international legal order, predominantly decentralized, depends for effectiveness on the acceptance by principal states of the fundamental ordering notions of symmetry, reciprocity, and national precedentsetting. ${ }^{.4}$

In analyzing the Memorandum I will adhere to its outline of issues, concentrating on the most significant.

Collective Self-Defense. The Memorandum argues that the United States may, at Saigon's request, participate in the collective self-defense of South Viet Nam because North Viet Nam has made a prior armed attack. But may indirect aggression be treated as an armed attack without the approval of an appropriate international institution? The United States rests its case on the role of Hanoi in the period between 1954 and 1959 in setting up "a covert political-military organization" and by its infiltration of "over 40,000 armed and unarmed guerrillas

52. An adversary debate may be useful to clarify the legal issues, but an impartial perspective is also needed to help in the process of choosing among the adversarj presen. tations.

53. America's relative inability to make effective legal protests against further nuclear testing on the high seas and in the atmosphere is partly a result of America's carlier legal defense of its own similar behavior. A legal precedent is created by the cffective assertion of a claim to act, and this precedent may be difficult to repudiate, even if the precedentsetter has greater power than does the actor relying upon the precedent.

54. See Falk, The Role of Donestic Courts in the Internatjonal Leall Order 21-52 (1964). 
into South Viet Nam" during the subsequent five years. The Memorandum concludes that "the external aggression from the North is the critical military element of the insurgency," that "the infiltration of thousands of armed men clearly constitutes an 'armed attack' under any reasonable definition," and that although there may be doubt as to "the exact date at which North Viet Nam's aggression grew into an 'armed attack,' [it certainly] had occurred before February 1965."

This argument is questionable on its face, that is, without even criticizing its most selective presentation of the facts. Consider first the highly ideological character of prevailing attitudes toward the just use of force. The Communist countries favor support for wars of national liberation; the West-in particular, the United States-favors support for anti-Communist wars; and the Afro-Asian states favor support for anti-colonialist and anti-racist wars. ${ }^{55}$ Consider also the importance, acknowledged by the United States in other settings, ${ }^{50}$ of circumscribing the right of self-defense. The use of force on some other basis-for example, defensive intervention or regional security-moderates rather than escalates a conflict. But the invocation of self-defense as a rationale during a conflict previously contained within a single state tends to enlarge the arena of conflict to include states that are claiming and counter-claiming that each other's intervention in the civil strife is an armed attack. If the infiltration constitutes an armed attack, the bombing of North Viet Nam may be justified. But if North Viet Nam had operative collective defense arrangements with China and the Soviet Union it is easy to project a scenario of escalation ending in global catastrophe. If, on the other hand, infiltration is merely intervention, and appropriate responses are limited to counter-intervention, the area of violence is restricted to the territory of South Viet Nam and its magnitude is kept within more manageable limits. ${ }^{57}$

The argument in the Memorandum also assumes that armed help to the insurgent faction is under all circumstances a violation of international law. As mentioned earlier, at some stage in civil strife it is

55. Compare with these claims the prohibitions upon the use of force expressed in absolute terms in Article 2(4) of the United Nations Charter. Self-defense against a prior armed attack appears to be the only permissible national basis for the use of force (without authorization from the United Nations).

56. See, e.g., avoidance of a self-defense rationale by government officials offering legal justification for the United States claims to interdict on the high seas Soviet intermediate range ballistics bound for Cuba in 1962. Mecker, Defensive Quarantine and the Law, 57 AM. J. INT'L L. 515 (1963); Chayes, The Legal Case for U.S. Action on Cuba, 47 DEp'T State BuLt. 763 (1962).

57. For a fuller rationale see Falk, supra note 4. 
permissible for outside states to regard the insurgent elite the equal of the incumbent regime and to render it equivalent assistance. ${ }^{5 s}$ Since no collective procedures are available to determine when an insurgency has proceeded far enough to warrant this status, outside states enjoy virtually unlimited discretion to determine the comparative legitimacy of competing elites. ${ }^{59} \mathrm{In}$ effect, then, no rules of international law exist to distinguish clearly between permissible and impermissible intervention in civil strife. ${ }^{60}$ To call hostile intervention not only impermissible but an instance of the most serious illegality-an armed attack-seems very unfortunate. In addition to a tendency to escalate any particular conflict, the position that interventions are armed attacks so broadens the notion of armed attack that all nations will be able to make plausible claims of self-defense in almost every situation of protracted internal war. It therefore seems desirable to confine the armed attack/selfdefense rationale to the Korea-type conflict (Type I) and to deny its applicability in Viet Nam, whether the war in Viet Nam is denominated Type II or Type III. The Memorandum's argument on self-defense is also deficient in that it relies upon a very selective presentation of the facts. It ignores Saigon's consistent opposition to the terms of the Geneva settlement, thereby casting in very different light Hanoi's motives for the steps it took in South Viet Nam to assert its claims. ${ }^{01}$ It is essential to recall that the pre-1954 conflict was waged for control of all of Viet Nam and that the settlement at Geneva was no more than "a cease-fire." President Diem's ruthless suppression of political opposition in South Viet Nam from 1954 onward, in violation of the ban on political reprisals included in the Geneva Agreements, is also relevant.o?

58. Cf. the study of the international relations of the insurgent groups during the Algerian War of Independence by M. BeDJAOUi, LAw AND THE Alcerian Revolution (1961).

59. If "the will of the international community" operates as the true basis of international law, the criteria of legitimacy shift to correspond to the values of the expanded membership in international society.

60. See LAUTERPACHT, op. cit. supra note 21, at 253-55.

61. If mutuality is the basic condition for the existence of a legal obligation, it is essential that both disputants accept the terms of settlement. If there is non-acceptance on one side, the other side is in a position to protect its position as if the settlement did not exist. In the setting of Viet Nam this would suggest that Hanoi was free to pursue its war aims on a pre-1954 basis and ignore the division of the country into two zones. It is ironic that South Viet Nam owes its original political identity entirely to the Geneva Agreements.

62. Cf. Article 15, Agreement on the Cessation of Hostilities: "Each party undertakes to refrain from any reprisals or discrimination against persons or onganizations for their activities during the hostilities and also undertakes to guarantee their democratic freedoms." Background Inforatation 50, 53. See Lacouture 28-31; Burciett, ViethiasINSIDE STORY OF THE GUERILA WAR 109-28 (1965). 
Furthermore, the injection of an American political and military presence was, from the perspective of Hanoi, inconsistent with the whole spirit of Geneva. ${ }^{63}$ The United States decision to commit itself to maintaining a Western-oriented regime in South Viet Nam upset the expectations regarding the Southeast Asian balance of power; in that respect, it was similar to the Soviet attempt to upset the Caribbean balance of power by installing intermediate-range missiles in Cuba in $1962 .{ }^{44}$

The Memorandum seems to concede that until 1964 the bulk of infiltrated men were South Vietnamese who had come north after the cease-fire in 1954. The use of exiles to bolster an insurgent cause appears to be on the borderline between permissible and impermissible behavior in contemporary international politics. The role of the United States Government in sponsoring the unsuccessful invasion at the Bay of Pigs in 1961 was a far more flagrant example of the use of exiles to overthrow a constituted government in a neighboring country than the early role of Hanoi in fostering an uprising in the South. ${ }^{06}$ The claim by the United States to control political events in Cuba is far more tenuous than the claim by North Viet Nam to exercise control (or at least remove the influence of a hostile superpower) over political life in the South. ${ }^{68}$ And Castro's regime was domestically viable in a manner that Saigon regimes have never been-suggesting that South Viet Nam presents a more genuine revolutionary situation than does contemporary Cuba. It seems more destructive of world order to help overthrow

63. The operative great power in the area was France. It was not in Hanoi's interest to give up a favorable battle position so that the United States could replace the French military presence. The worsening of their position in the area as a result of the ncgo. tiations at Geneva may explain, in part, their reluctance to negotiate a "settlement" and give up a favorable military position once again.

64. One influential view of the basis of international order stresses maintaining current balances and expectations. Any attempt to rely upon military means to upset these balances and expectations is perceived and treated as "aggression." The intrusion of Sovict military influence into the Western Hemisphere by attempting to emplace missiles constituted the provocative element. The same military result could have been achieved by increasing the Atlantic deployment of missile-carrying submarines. This sense of "provocative" might also describe the perception of the escalating American military commitment in Southeast Asia.

65. For an authoritative account of the United States role sce Scillesingen, JR, $A$ Thousand DAYs 206-97 (1965).

66. The strength of Hanoi's claim arises from the prior struggle to control the cntire country, the military victory by the Vietminh in that struggle, the expectations creatcd at Geneva that the elections would confirm that military victory, the delimitation of South Viet Nam as "a temporary zone," and, finally, the refusal by South Viet Nam to consult on elections or to refrain from reprisals. 
a firmly established government than to assist an ongoing revolution against a regime incapable of governing.

African countries admit helping exiles overthrow governments under white control. ${ }^{67}$ American support for Captive Nations Week is still another form of support outside of the Communist bloc for exile aspirations. ${ }^{68}$ In short, international law neither attempts nor is able to regulate support given exile groups. The activities of Hanoi between 1954 and 1964 conform to patterns of tolerable conflict in contemporary international politics.

The Memorandum contends that subsequent to 1964, Hanoi has increasingly infiltrated regular elements of the North Vietnamese army until at present "there is evidence that nine regiments of regular North Vietnamese forces are fighting in the South." Arguably, the N.L.F. was not eligible to receive external support in the early years of strife after 1954, as its challenge to the government amounted to no more than "a rebellion." But certainly after the Vietcong gained effective control over large portions of the countryside it was permissible for North Viet Nam to treat the N.L.F. as a "belligerent" with a right to conduct external relations. ${ }^{99}$ This area of international law is exceedingly vague; states have a wide range of discretion in establishing their relations with contending factions in a foreign country..$^{70}$

The remainder of the first section of the Memorandum responds to the Lawyers Committee Memorandum of Law, but is not relevant to the solution of the critical legal questions. It is persuasive but trivial for the State Department to demonstrate that international law recognizes the right of individual and collective self-defense against an armed

67. In the Final Act of the Conference of Heads of States or Governments at Cairo in 1964 the following declaration was made by the forty-seven non-aligned powers aseembled: "Colonized people may legitimately resort to arms to secure the full exercise of their right to self-determination."

68. For perceptive discussion of the status of "Captive Nations Weck" in international law see Wright, Subversive Intervention, 54 AM. J. INT'L L. 521 (1960).

69. See the extent of international recognition accorded the F.L.N. in Algeria during their war against the French, BEDJAOuI, op. cit. supra note 58, at 110-38.

70. No clear rules of prohibition nor any required procedures exist which subject national discretion to international review. National discretion consequently governs practice.

For useful discussions stressing the survival under the United Nations Charter of a wider right of self-defense than the interpretation offered here see BOwETr, SELF-DEFENSE IN INTERNATIONAL LAW 182-99 (1958); MaDougal \&: FeliclaNo, LAw aNd MinimuM Wored Public ORder 121-260 (1961); for a position similar to the one taken in the text see Henkin. Force, Intervention and Neutrality in Contemporary International Low, 1983 Proc Ass. Soc. INT'L I. 147-62. 
attack; that non-members of the United Nations enjoy the same rights of self-defense as do members; ${ }^{71}$ that South Viet Nam is a political entity entitled to claim the right of self-defense despite its origin as a "temporary zone"; ${ }^{22}$ and that the right of collective self-defense may be exercised independent of a regional arrangement organized under Chapter VIII of the United Nations Charter. ${ }^{73}$ South Viet Nam would have had the right to act in self-defense if an armed attack had occurred, and the United States would then have had the right to act in collective self-defense. ${ }^{74}$

It is also important to determine whether the United States has complied with the reporting requirement contained in Article 51 of the United Nations Charter. ${ }^{75}$ The United States did encourage a limited Security Council debate during August 1964 of the Gulf of Tonkin "incidents."76 Furthermore, the United States submitted two reports to the Security Council during February 1965 concerning its recourse to bombing North Viet Nam and the general character of the war. And in January 1966 the United States submitted the Viet Nam question to the Security Council. ${ }^{77}$ It seems reasonable to conclude that the Security Council (or, for that matter, the General Assembly) is unwilling and unable to intervene in any overt manner in the conflict in

71. For consideration of this question see BowETr, op. cit. supra note 70, at 198.95.

72. See the first sentence of Article 6 of the Final Declaration: "The Conference recog. nizes that the essential purpose of the agreement relating to Viet-Nam is to settle military questions with a view to ending hostilities and that the military demarcation line is provisional and should not in any way be interpreted as constituting a political or territorial boundary," BACKGROUND INFORMation 58, 59. (Emphasis added.) For Saigon's relevant conduct see LAcouture 24-31.

73. For a useful analysis see BowetT, op. cit. supra note 70, at 200.48; MaDovant. \& Feliciano, op. cit. supra note 70, at 244-53.

74. That is, it would conform to expectations about what constitutes a permissible claim to use force in self-defense. Despite considerable controversy about the wisdom of the United States' involvement in the defense of Korea, there was no debate whatsocver (outside of Communist countries) about the legality of a defensive claim. There was some legal discussion about the propriety of United Nations involvement. For an argument in favor of legality see McDougal \& Gardner, The Veto and the Charter: An Interpretation for Survival, in McDougal \& Associates, Studies iN Wordd Punlic ORder 718.60 (1060). In retrospect, however, Korea exemplifies "an armed attack" for which force in response is appropriate, even if used on the territory of the attacking state.

75. For communications sent by the United States to the United Nations and relied upon to show compliance with the reporting requirements of Article 51 see VietNAM Hearings $634-40$.

76. For a description of official United States views see Promoting the Mainlenance of International Peace and Security in Southeast Asia, H.R. REP. No. 1708, 88th Cong., 2d Sess. (1964); see Ambassador Stevenson's statement to the Security Council on August 5 , 1964, in BAGRGROUND INFORMATION 124-28.

77. No action was taken by the United Nations and the debate was inconclusive and insignificant. 
Viet Nam. This conclusion is reinforced by the hostility of the Communist states toward American proposals for a settlement..$^{78}$ On the other hand, there is no evidence of formal initiative by the members of the United Nations to question the propriety of the United States policies. The very serious procedural question posed is whether the failure of the United Nations to act relieves the United States of its burden to submit claims of self-defense to review by the organized international community. ${ }^{79} \mathrm{~A}$ further question is whether any international legal limitations upon national discretion apply when the United Nations refrains from passing judgment on claims to use force in self-defense. ${ }^{80}$

The Security Council failed to endorse American claims in Viet Nam, and this failure was not merely a consequence of Soviet or Communist opposition. Therefore, if the burden of justification for recourse to self-defense is upon the claimant, inaction by the United Nations provides no legal comfort on the substantive issue-that is, the legality of proportional self-defense given "the facts" in Viet Nam. As to the procedural issue - that is, compliance with the reporting requirement of Article 51-the United States may be considered to have complied pro forma, but not in terms of the spirit of the Charter of the United Nations.

The overriding purpose of the Charter is to commit states to use force only as a last resort after the exhaustion of all other alternatives. In the early period after 1954 the United States relied heavily on its unilateral economic and military capability to protect the Saigon regime against the Vietcong. No prior attempt was made, in accordance with Article 33 , to settle the dispute by peaceful means. ${ }^{81}$ Yet the spirit of the

78. Neither China nor North Viet Nam indicate any willingness to acknowledge a role for the United Nations. Of course, the exclusion of China from representation in the United Nations may account for Chinese opposition to a U.N. solution. Sce also AD Hoc Congressional Conference 5.

79. To what extent, that is, do states have residual discretion to determine the legality of claims to use force in the event of United Nations inability to reach a clear decision?

80. The nature of these restraints may be of two varicties: first, the considerations entering into the creation of a precedent; second, the restraints of customary international Iaw requiring that minimum necessary force be used to attain belligerent objectives and requiring the maintenance of the distinction between military and non-military targets and between combatants and non-combatants. One wonders whether these latter distinctions can be maintained in a guerrilla war such as that in Viet Nam.

81. U.N. CHARTER art. 93(I):

The parties to any dispute, the continuance of which is likely to endanger the maintenance of international peace and security, shall, first of all, seek a solution by negotiation, enquiry, mediation, conciliation, arbitration, judicial setuement, resort to regional agencies or arrangements, or other peaceful means of their own choice. 
Charter requires that a nation claiming to undertake military action in collective self-defense must first invoke the collective review and responsibility of the United Nations. The United States did not call for United Nations review until January 1966, that is, until a time when the prospects for a favorable military solution at tolerable costs seemed dismal, many months subsequent to bombing North Vietnamese territory. As long as a military victory was anticipated, the United States resented any attempt to question its discretion to use force or to share its responsibility for obtaining a settlement. ${ }^{82}$ American recourse to procedures for peaceful settlement came as a last rather than a first resort. The United States had made no serious effort to complain about alleged North Vietnamese violations of the Geneva Agreements, nor to recommend a reconvening of a new Geneva Conference in the decade of escalating commitment after 1954. Saigon submitted complaints to the International Control Commission, but that body was neither constituted nor intended to deal with the resumption of a war for control of South Viet Nam that was apparently provoked by Saigon's refusal to hold elections.

Further, not until 1965 did the United States welcome the independent efforts of the Secretary-General to act as a negotiating intermediary between Washington and Hanoi. ${ }^{83}$ Until it became evident that a military victory over the Vietcong was not forthcoming, the United States Government was hostile to suggestions emanating from either U Thant (or De Gaulle) that a negotiated settlement was both appropriate and attainable. The State Department's belated offer to negotiate must be discounted in light of its public relations overtones and our effort over the last decade to reverse the expectations of Geneva. The United States negotiating position is also made less credible by our failure to accord the N.L.F. diplomatic status as a party in conflict. ${ }^{84}$ This failure is especially dramatic in light of the N.L.F.'s ability effectively to govern territory under its possession and Saigon's relative inability to do so.

The American approach to negotiations lends support to the conclusion that our sporadic attempts at a peaceful settlement are belated gestures, and that we seek "victory" at the negotiating table only when it becomes unattainable on the battlefield. The United States showed no willingness to subordinate national discretion to the collective will of the organized international community. In fact, Viet Nam exempli-

82. Cf. note 39 supra.

83. Cf. note 38 supra.

84. See the recommendations to this effect in Ad Hoc Congressional Conference $b$. 
fies the American global strategy of using military power whenever necessary to prevent Communist expansion and to determine these necessary occasions by national decisions. This militant anti-Communism represents the essence of unilateralism. ${ }^{85}$

One must conclude that the United States was determined to use its military power as it saw fit in Viet Nam in the long period from 1954 to January 1966. In 1966 at last a belated, if halfhearted, attempt to collectivize responsibility was made by appealing to the Security Council to obtain, in the words of the Memorandum, "discussions looking toward a peaceful settlement on the basis of the Geneva accords." The Memorandum goes on to observe that "Indeed, since the United States submission on January 1966, members of the Council have been notably reluctant to proceed with any consideration of the Viet-Nam question." Should this reluctance come as a surprise? Given the timing and magnitude of the American request it was inevitable that the United Nations would find itself unable to do anything constructive at that stage. United Nations inaction has deepened the awareness of the Organization's limited ability to safeguard world peace, whenever the nuclear superpowers take opposite sides of a violent conflict. ${ }^{80}$ Disputes must be submitted prior to deep involvement if the United Nations is to play a significant role. ${ }^{87}$ The war in Viet Nam presented many appropriate opportunities-the various steps up the escalation ladder-for earlier, more effective, American recourse to the United Nations. But during the entire war in Viet Nam, the United States has shown no significant disposition to limit discretionary control over its national military power by making constructive use of collective procedures of peaceful settlement.

Proportionality. Even if we grant the Memorandum's contention that North Viet Nam is guilty of aggression amounting to an armed attack and that the United States is entitled to join in the collective selfdefense of South Viet Nam, important questions remain concerning

85. That is, it represents the claim to use force for purposes determined by the United States. The ideological quality of this unilateralism-its quality as an anticommunist crusade-is suggested by "the understanding" attached by the United States to its ratification of the SEATO treaty limiting "its recognition of the effect of aggression and armed attack ... to communist aggression." It is very unusual to restrict the applicability of a security arrangement in terms of the ideological identity of the aggressor, rather than in terms of national identity or with reference to the character of the aggres. sion.

86. For a generalized approach to the problems of international conflict given the structure of international society, see F. Gross, Worrd Polmis AND TENision AREAs (1960).

87. In the Congo Operation the outer limits of United Nations capacity were tested, perhaps exceeded. 
the quantum, ratio, and modalities of force employed. Elementary principles both of criminal and international law require that force legitimately used must be reasonably calculated to attain the objective pursued and be somewhat proportional to the provocation. As McDougal and Feliciano observe, "[U]nderlying the processes of coercion is a fundamental principle of economy." 88 This fundamental principle deriving from the restraints on violence found in the earliest version of the just war doctrine has two attributes: the effectiveness of the force employed and the avoidance of excessive force. ${ }^{80}$

The United States effort in Viet Nam combines ineffectual with excessive force. The level of military commitment to date seems designed to avert defeat rather than to attain victory. All observers agree that if the other side persists in its commitment, the search for a favorable military solution will be exceedingly prolonged. Since the United States has far greater military resources potentially available, our use of insufficient force violates general norms of international law. ${ }^{00}$ At the same time, however, weapons and strategy are being employed to cause destruction and incidental civilian damage without making a proportional contribution to the military effort. This is particularly true of our reliance upon strategic area bombing against dispersed targets of small military value. ${ }^{91}$

The United States has at each juncture also claimed the legal right to engage in disproportionate responses to specific provocations. In August 1964 the Gulf of Tonkin incidents consisted of allegations that North Vietnamese torpedo boats had "attacked" some American warships on the high seas. Although no damage was reported the United States responded by destroying several villages in which the boats were

88. MaDougal \& Feliciano, op. cit. supra note 70, at 35.

89. Implicit in the notion of economy of force is the idea that an unjust and lllegal use of force is a futile use. The idea of futility is related to the attainability of a permissible belligerent objective and is difficult to measure. If a negotiated settlement rather than victory is the objective, the amount of force required can only be assessed in tcrms of the probable intentions of the other side, and these shift in response to many factors, including their assessment of intentions.

90. Here again a reinterpretation of traditional thinking on war is needed to satisfy the requirements of the nuclear age. American restraint in Viet Nam is explained in part by concern with generating a nuclear war or, at least, provoking a wider war in Southeast Asia. But what legal consequences follow if this inhibition leads to prolonged violence in Viet Nam of an indecisive but devastating form?

91. The Conference participants were in agreement that the bombings in the north were of little military value, while the diplomatic disadvantages were very serious. Further escalation of the bombings, it was felt, could not be expected to improve the situation.

ad Hoc Congressional Conference 4. 
based. ${ }^{92}$ This was the first occasion on which force was used directly against North Vietnamese territory and the justifications rested upon a reprisal theory that was largely disassociated from the war in South Viet Nam. Such a disproportionate ratio between action and reaction is typical of great power politics in which superior force is used to discipline a minor adversary. But this exaggerated response violates the legal requisites of equivalency and symmetry between the injury sustained and the response undertaken. Acceptance of mutuality and symmetry is basic to the whole conception of law in a sovereignty-centered social order. ${ }^{93}$

The bombing of North Viet Nam in February 1965 was also originally justified as a "reprisal" for a successful attack by the Vietcong upon two United States air bases, principally the one at Pleiku. Only in retrospect was the justification for attacking North Viet Nam generalized to collective self-defense of South Viet Nam. ${ }^{34}$

No clear legal guidelines exist to measure the proportionality of force used in self-defense. There is also some doubt whether proportionality applies to the belligerent objective pursued or the size and character of the aggression. If we assume that the appropriate quantum of military force is that needed to neutralize the Vietcong (the mere agent, in the American view, of Hanoi), then our military response (given our capability) appears to be disproportionately low. A guerrilla war can be won only by a minimum manpower ratio of $10: 1$, whereas the present ratio is no better than 5:1. Our present level of commitment of military forces merely prolongs the war; it does not aim to restore peace by means of victory.95

If on the other hand, North Viet Nam and the United States are considered as foreign nations intervening on opposite sides of an armed conflict, then in terms of money, materiel, manpower, and overtness the United States has intervened to a degree disproportion-

92. For a rather effective presentation of the North Vietnamese version of uhe Tonkin Incidents see Nguyen Nghe, Facing the Skyhawks (pamphlet printed in Hanoi, 1964). For an attack on the legality of the United States response see I. F. Stone, International Law and the Tonkin Bay Incidents, in VIET-NAM READER 307-15. For the U.S. position see references cited note 94 infra.

93. Cf. Kunz, The Distinctiveness of the International Legal System, 22 OHo St. L.J. 447 (1961).

94. Cf. the White House Statement of February 7, 1965, BAckground INForuarno: 146-47; see also id. at 148-52 for the context used to justify extending the war to North Viet Nam. No charge is made that the attacks on United States military installations were ordered or performed by North Viet Nam personnel.

95. Cf. note 41 supra; see also General Gavin's testimony before the Senate Foreign Relations Committee, Vietnam Henrinas 270-71. 
ately greater than has North Viet Nam.06 In the early period of the war the Vietcong captured most of its equipment from the Saigon regime and the level of material support from the North was low.

The objective of American military strategy is apparently to destroy enough that is important to Hanoi and the N.L.F. to bring about an eventual de facto reduction of belligerent action or to force Hanoi to make a satisfactory offer of negotiations. Are there any legal rules that restrict such a strategy in terms of duration, intensity, or destruction? This question seems so central to the future of international law that it is regrettable, to say the least, that the Memorandum does not discuss it. That formalistic document implies that if a state claims to use force in self-defense, and supports its claim with a legal argument, and if the United Nations does not explicitly overrule that claim, international law has nothing further to contribute. ${ }^{97} \mathrm{I}$ would argue, in contrast, that it is crucial to determine what limiting considerations come into play at this point. It is certainly a regressive approach to international law to assume that if a state alleges "self-defense," it may in its untrammeled discretion determine what military action is reasonably necessary and proportional. The opposing belligerent strategies in Viet Nam seem to call for legal explanation, especially in view of the inability of either side to "win" or "settle" the war; the present standoff causes great destruction of life and property without progressing toward "a resolution" of the conflict.

The Relevance of Commitments to Defend South Viet Nam. The second main section of the Legal Adviser's Memorandum is devoted to establishing that the United States "has made commitments and given assurances, in various forms and at different times, to assist in the defense of South Viet-Nam." Much confusion is generated by a very misleading play on the word commitment. In one sense, commitment means a pledge to act in a specified manner. In another sense, commitment means an obligation of law to act in a specified manner.

During 1965-66 the United States clearly came to regard itself as having made a commitment qua pledge to assist in the defense of South Viet Nam. President Johnson expressed this pledge on many occasions. Two examples are illustrative:

96. For an account of some features of the escalation see MANSFIELD, ET AL., REYORT TO Senate foreign Relations Comm., 89th Cong., 2d Sess., The Vietnam Confligr: The Substance and the Shadow (Comm. Print Jan. 6, 1966). Sce also Sianten xii, xxii; VietNAM WITNESS $307-49$.

97. A state, in effect, satisfies the requirements of international law merely by filing a brief on its own behalf. 
We are in Viet Nam to fulfill one of the most solemn pledges of the American nation. Three Presidents-President Eisenhower, President Kennedy, and your present President-over 11 years have committed themselves and have promised to help defend this small and valiant nation.98

We are there because we have a promise to keep. Since 1954 every American President has offered support to the people of South Viet Nam. We have helped to build, and we have helped to defend. Thus, over many years, we have made a national pledge to help South Viet Nam defend its independence.93

The present commitment entailing a major military effort is of a very different order than the early conditional offers of economic and military assistance made by President Eisenhower. ${ }^{100}$ American involvement in Vietnam is usually traced to a letter from President Eisenhower to Diem on October 23, 1954, in which the spirit of the undertaking was expressed in the following sentence: "The purpose of this offer is to assist the Government of Viet-Nam in developing and maintaining a strong, viable state, capable of resisting attempted subversion or aggression through military means." The letter contains no hint of a pledge. In fact, the United States conditions its offer to assist with a reciprocal expectation: "The Government of the United States expects that this aid will be met by performance on the part of the Government of Viet-Nam in undertaking needed reforms."101 It is important to note that the letter contained no reference to SEATO despite the formation of the organization a few weeks before it was written, and that the role of the United States was premised upon satisfactory domestic progress in South Viet Nam.

As late as September 1963, President Kennedy said in a TV interview: "In the final analysis, it is their war. They are the ones who have to win it or lose it. We can help them, we can give them equipment, we can send our men out there as advisers, but they have to win it-the people of Viet Nam-against the Communists. We are prepared to continue to assist them, but I don't think that the war can be won unless the people support the effort. ..."102 This expression of American involvement emphasizes its discretionary and reversible character, and again implies that the continuation of American assistance is condi-

98. N.Y. Times, July 29, 1965.

99. N.Y. Times, April 8, 1965.

100. Larson \& Larson, Vietnan and Beyond 17-29 (1965).

101. BACKGROUND INFORMATION 67-68.

102. Id. at 99. 
tional upon certain steps being taken by the Saigon regime. Even in 1965 Secretary Rusk in an address to the Annual Meeting of the American Society of International Law, provided a legal defense of the United States position in Viet Nam that stopped short of averring a commitment qua legal obligation. Mr. Rusk did not once refer to SEATO in his rather complete coverage of the subject. The crucial explanation of the American presence is contained in the following passage:

In resisting the aggression against it, the Republic of Viet-Nam is exercising its right of self-defense. It called upon us and other states for assistance. And in the exercise of the right of collective self-defense under the United Nations Charter, we and other nations are providing such assistance. The American policy of assisting South Viet-Nam to maintain its freedom was inaugurated under President Eisenhower and continued under Presidents Kennedy and Johnson. ${ }^{103}$

Each successive increase in the level of American military involvement has been accompanied by an intensification of rhetoric supporting our presence in Viet Nam. By 1965 President Johnson was, as we observed, referring to Viet Nam as "one of the most solemn national pledges." It is disconcerting to realize that the United States has at each stage offset a deteriorating situation in South Viet Nam by increasing both its military and rhetorical commitment. This process discloses a gathering momentum; at a certain point, policy becomes virtually irreversible. President Johnson's use of the rhetoric of commitment communicates the irreversibility of this policy and conveys a sense of the futility and irrelevance of criticism. If we have a commitment of honor, contrary considerations of prudence and cost are of no concern. ${ }^{104}$

But no commitment qua pledge has the capacity to generate a commitment qua legal obligation. The Administration seems to want simultaneously to invoke both senses of the notion of commitment in order to blunt and confuse criticism. A commitment qua legal obligation is, by definition, illegal to renounce. To speak of commitment in a legal memorandum is particularly misleading. To the extent that we have any commitment it is a pledge of policy.

Secretary Rusk has injected a further confusion into the debate by his stress on "the SEATO commitment" in the course of his testimony

103. Rusk, Address, 1965 Proc. AMr. Soc. INT't L. 251-52.

104. For this reason the Administration is hostile to domestic criticism. It is, above all, unresponsive to this qualitative aspect of our presence in Viet Nam. Gf. President Johnson's speech at Johns Hopkins University on April 7, 1965, in Vietnam Hearings 640.44 . 
before the Senate Foreign Relations Committee in the early months of $1966 .{ }^{105}$ He said, for instance, in his prepared statement: "It is this fundamental SEATO obligation that has from the outset guided our actions in Vietnam." 106 The notion of the obligation is derived from Article IV (I) of the SEATO treaty which says that "each party recognizes that aggression by means of armed attack . . . would endanger its own peace and safety, and agrees that it will in that event act to meet the common danger in accordance with its constitutional processes." It is somewhat doubtful that Article IV(1) can be properly invoked at all in Viet Nam because of the difficulty of establishing "an armed attack." 107 Secretary Rusk contends, however, that this provision not only authorizes but obliges the United States to act in the defense of South Viet Nam.108

Ambiguity again abounds. If the commitment to act in Viet Nam is incorporated in a treaty, the United States is legally bound. Such an interpretation of Article IV(1) would apply equally to other states that have ratified the SEATO treaty. None of the other SEATO signatories acknowledge such "a commitment" to fulfill a duty of collective selfdefense, nor does the United States contend they have one. France and Pakistan oppose altogether any military effort on behalf of the Saigon regime undertaken by outside states.

Secretary Rusk later softened his insistence that Article IV(l) imposed a legal commitment qua obligation upon the United States. In an exchange with Senator Fulbright during Senate hearings on Viet Nam, Mr. Rusk offered the following explanation:

The Chairman. . . . do you maintain that we had an obligation under the Southeastern Asian Treaty to come to the assistance, all-out assistance of South Vietnam? Is that very clear?

Secretary Rusk. It seems clear to me, sir, that this was an obligation-

105. Id. at 567. Secretary Rusk explains to the Senate Foreign Relations Committee that "the language of this treaty is worth careful attention. The obligation it imposes is not only joint but several. That is not only collective but individual.

"The finding that an armed attack has occurred does not have to be made by a collective determination before the obligation of each member becomes operative." Cf. the shifting views of SEATO obligation recounted in Young, The Southeast Asia Crisis, 1963 HassMARSKJOLD FORUM 54. Even Mr. Young, a staunch defender of administration policj, notes that "Until the crisis in Laos in 1961, the United States looked upon SEATO as a collective organization which would take military action, with all eight members participating in the actions as well as the decision." Id. at 59.

106. VIETNAM HeArINGS 567; note the absence of reference to SEATO in Rusk, supre note 103 , and in the 1965 legal memorandum, supra note 45.

107. See generally SEATO, 3-45, 87-163 (Modelski ed. 1962).

108. VIETNAM HEARINGS $56 \%$. 
The Chairman. Unilateral.

Secretary Rusk. An obligation of policy. It is rooted in the policy of the treaty. I am not now saying if we had decided we would not lift a finger about Southeast Asia that we could be sued in a court and be convicted of breaking a treaty. ${ }^{100}$

It seems evident if an armed attack has been established, the treaty imposes a legal obligation to engage in collective self-defense of the victim. But in the absence of a collective determination by the SEATO membership that an armed attack has taken place, it is difficult to maintain that Article IV(1) does more than authorize discretionary action in appropriate circumstances.

The Memorandum argues that "the treaty does not require a collective determination that an armed attack has occurred in order that the obligation of Article IV(1) become operative. Nor does the provision require collective decision on actions to be taken to meet the common danger." 110 This interpretation of Article IV(l) is a blatant endorsement of extreme unilateralism, made more insidious by its pretense of "obligation" and its invocation of the multilateral or regional scaffolding of SEATO. Here the legal position of the State Department displays maximum cynicism, resorting to international law to obscure the national character of military action. In essence, the United States claims that it is under an obligation to determine for itself when an armed attack has occurred, and that once this determination is made there arises a further obligation to act in response. This justification for recourse to force is reminiscent of the international law of war prior to World War I, when states were free to decide for themselves when to go to war. ${ }^{111}$ The regressive tendency of this position is further intensified by applying it in a situation where there was a background of civil war and where the alleged aggression was low-scale, extended over time, and covert. Under "the Rusk Doctrine" a country alleging "armed attack" seems free to act in self-defense whenever it wishes. The rhetoric of commitment seems connected with the effort to make the policy of support for Saigon irreversible in domestic arenas and credible in external arenas, especially in Saigon and Hanoi, but it has little to do with an appreciation of the relevance of international law to United States action in Viet Nam.

The important underlying question is whether it is permissible to

109. Id. at 45; see also id. at 7-8.

110. Id. at 567 .

111. For a general survey of progressive attempts to regulate recourse to war sce Wright, The Role of INTERnational LAW in the Elimination of WaR (1961). 
construe an occurrence of "an armed attack" in the circumstances of the internal war in South Viet Nam. If an armed attack can be held to have occurred, then both self-defense and collective self-defense are permissible. The legal status of a claim of collective self-defense is not improved by embedding the claim in a collective defense arrangement. In fact, the collective nature of an arrangement such as SEATO might imply some obligation to attempt recourse to consultative and collective procedures before acting, at least to determine whether an armed attack has occurred and by whom. Under Secretary Rusk's interpretation of the treaty, SEATO members with opposing views on the issue of which side committed an armed attack could become "obligated" to act in "collective self-defense" against one another. ${ }^{112}$ Surely this is the reductio ad absurdum of collective self-defense.

In terms of both world order and the original understanding of SEATO, the conflict in Viet Nam calls for action, if at all, under Article $\Pi V(2) .{ }^{113}$ To categorize the conflict under Article $\Gamma(1)$ would seem to require a unanimous collective determination that the assistance given by Hanoi to the Vietcong amounted to an armed attack. Once that determination had been made, it might seem plausible to maintain that the obligation to act in collective self-defense exists on a joint and several basis, and that the United States might join in the defense of the victim of the armed attack without further collective authorization. Unlike the State Department position, the approach outlined in this paragraph requires that a multilateral determination of the facts precede acts of commitment. The United States might help build a more peaceful world by taking seriously the collective procedures governing the use of force which it has taken such an active role in creating.

The Geneva Accords of 1954. The agreements at Geneva were cast in the form of a cease-fire arrangement and a declaration of an agreed procedure for achieving a post-war settlement. The parties to the first war in Viet Nam were the French and the Vietminh, and the agreements were between their respective military commanders. The other powers at Geneva were mere sureties. At Ho Chi Minh's insistence the Saigon regime did not participate; Saigon was evidently dissatisfied from the outset with the terms of settlement.114 The United States

112. E.g., suppose Laos and Thailand became involved in a conflict in which each state accused the other of being an aggressor-and this is not impossible.

113. Cf. SEATO op. cit. supra note 107, at xiv. It is made clear both that intemal conflicts abetted by subversion were to be treated under Article IV(2) and that this provision required consultation as a prerequisite to action and had become "a dead letter."

114. See Viet-NAM WrTness 74-83. Jean Lacouture has written recenty that France 
Government was also reluctant to regard the Geneva settlement as binding. ${ }^{115}$

The Final Declaration required elections to be held in July of 1956 "under the supervision of an international commission composed of representatives of the Member States of the International Supervisory Commission." 118 The Memorandum points out that South Viet Nam "did not sign the cease-fire agreement of 1954, nor did it adhere to the Final Declaration of the Geneva Conference" and adds that "the South Vietnamese Government at that time gave notice of its objection in particular to the election provisions of the accords." At the time of the Geneva proceedings, the Saigon regime exerted control over certain areas in the South, and this awkward fact made it unrealistic to suppose that the Geneva terms of settlement would ever be voluntarily carried out. When Diem came to power and the United States moved in to fill the place left vacant by the departure of the French, it became clear, especially in view of the nation-wide popularity of Ho Chi Minh, that the contemplated elections would never be held. ${ }^{117}$ In a sense it was naive of Hanoi to accept the Geneva arrangement or to rely upon its implementation. 118

Saigon objected to the election provisions from the outset because it hoped for a permanent partition of Viet Nam. But permanent partition was so deeply incompatible with the objective sought by the Vietminh in the war against the French that it is hardly reasonable to expect Hanoi to acquiesce. In a sense, Hanoi's willingness to cooperate with the Geneva arrangement until 1956 is more surprising than is its later effort to revive the war in Viet Nam.

The Memorandum says that even assuming the election provisions were binding on South Viet Nam, there was no breach of obligation arising from Saigon's failure "to engage in consultations in 1955, with a view to holding elections in 1956." The justification offered for Saigon's action is that "the conditions in North Viet Nam during that period were such as to make impossible any free and meaningful ex. pression of popular will." But the election provision in the Final Decla-

bears a heavy responsibility for its failure to secure full implementation of the Geneva "solution" before withdrawing from Viet Nam; in Lacouture's view France's premature withdrawal created a political vacuum immediately filled by the United States. LAcouture 657.

115. VIET-NAM WITNESS 69-83; see LANCASTER 313-58 for a general account of the Geneva settlement.

116. See Article 7, Final Declaration of Geneva Conference, July 21, 1954, BAckGround INEORMATION $58,59$.

117. LANGASTRR 315-16.

118. Id. at 313-37. 
ration stated no preconditions about the form of interim government in the two zones, and the type of governmental control existing in the North could have been and presumably was anticipated by those who drew up the Final Declaration. The meaning of "free elections" in Communist countries was well known to all countries including the United States, and the conditions prevailing in South Viet Nam were no more conducive to popular expressions of will.110 The real objection to the elections was a simple one-namely, the assurance that Ho Chi Minh would win..$^{120}$ The Memorandum offers only a self-serving endorsement of Saigon's refusal to go along with the terms of settlement, although they had been endorsed by the United States representative, Bedell Smith.121

The Memorandum suggests in footnote 10, that North Viet Nam's remedies, had there been "a breach of obligation by the South, lay in discussion with Saigon, perhaps in an appeal to the co-chairmen of the Geneva conference, or in a reconvening of the conference to consider the situation." In light of the failure of the United States to make use of international remedies which it argues are obligatory for Hanoi, this statement is a shocking instance of legal doubletalk. Footnote 10 ends by saying that "Under international law, North Viet Nam had no right to use force outside its own zone in order to secure its political objectives." This again is misleading. No authoritative rules govern the action of the parties in the event that a settlement of internal war breaks down. Certainly if the settlement is not binding on all the parties, no one of them is bound by its constraints. In the absence of the Geneva Accords, Saigon would not exist as a political entity. If Saigon repudiates the Accords, Hanoi would seem to be legally free to resume the pursuit of its political objectives and to ignore the creation of a temporary zone in the South. The principle of mutuality of obligation makes it inappropriate to argue that Saigon is free to ignore the Geneva machinery but that Hanoi is bound to observe it.

Furthermore, international law does not forbid the use of force within a single state. If Hanoi may regard Viet $\mathrm{Nam}$ as a single country between 1954 and 1956, its recourse to force in pursuit of political objectives is not prohibited even assuming that its "guidance" and "direction" of the Vietcong constitute "a use" of force by North Viet Nam.

The Memorandum misleadingly implies that the International Con-

119. On the conduct of elections in Viet Nam see Fall, Vietnam's Twelve Elections, The New Republic, May 14, 1966, pp. 12-15.

120. WARNER 84-106, 142-43; cf. VIETNaM 191-94, 210.35 (Getuleman ed.).

121. For text of Smith's statement see BAckground INForsintion 61. 
trol Commission (ICC) endorsed the action of the United States and Saigon and condemned the action of North Viet Nam. Both sides were criticized severely by the ICC for violating provisions of the Geneva Accords. ${ }^{122}$ It would appear that the massive military aid given to Saigon by the United States was the most overt and disrupting violation, directly contravening the prohibition on the entry of foreign military forces and new military equipment. ${ }^{123}$ According to the reasoning of footnote 10, North Viet Nam's remedy lay in discussion and the Geneva machinery. But a quite different line of legal reasoning is taken to justify American activity: ${ }^{124}$ action otherwise prohibited by the Geneva Accords is "justified by the international law principle that a material breach of an agreement by one party entitles the other at least to withhold compliance with an equivalent, corresponding, or related provision until the defaulting party is prepared to honor its obligations." One wonders why this "international law principle" is not equally available to North Viet Nam after Saigon's refusal even to consult about holding elections. Why is Hanoi bound by the reasoning of footnote 10 and Washington entitled to the reasoning of reciprocal breach? The self-serving argument of the Memorandum confers competence upon the United States and Saigon to find that a breach has taken place and to select a suitable remedy, but permits Hanoi only to allege a breach, and forbids it to take countervailing action until the breach has been impartially verified.

The Authority of the President under the Constitution. I agree with the Legal Adviser's analysis that the President possesses the constitutional authority to use American military forces in Viet Nam without a declaration of war. Past practice and present policy support this conclusion. To declare war against North Viet Nam would further rigidify our own expectations about an acceptable outcome and it would almost certainly escalate the conflict. It might activate dormant collective defense arrangements between North Viet Nam and its allies.

But the Constitution is relevant in another way not discussed by the Memorandum. The President is bound to act in accordance with governing law, including international law. The customary and trenty norms of international law enjoy the status of "the law of the land" and the President has no discretion to violate these norms in the course

122. For a representative sample see VIETNAM, op. cit. supra note 120 , at 160.90 .

123. Cf. Articles 17, 18, Agreement on the Cessation of Hostilities in Vietnam, BACKGROUND INFORMATION 28, 34-35.

124. Cf. Department of State White Paper, Aggression from the North, in Viet-Nas REAdER 143-55; for criticism see Stone, A Reply to White Paper, in ViET-Nam Readen 155-62. 
of pursuing objectives of foreign policy. An impartial determination of the compatibility of our action in Viet Nam with international law is highly relevant to the constitutionality of the exercise of Presidential authority in Viet Nam.

The President has the constitutional authority to commit our armed services to the defense of South Viet Nam without a declaration of war provided that such "a commitment" is otherwise in accord with international law. Whether all or part of the United States action violates international law is also a constitutional question. International law offers no authoritative guidance as to the use of force wilhin South Viet Nam, but the bombing of North Viet Nam appears to be an unconstitutional use of Presidential authority as well as a violation of international law.

\section{IV}

It is appropriate to reflect on the role of the international lawyer in a legal controversy of the sort generated by our role in Viet Nam. The rather keen interest in this controversy about international law results mostly from intense disagreement about the overall wisdom of our foreign policy rather than curiosity about the content of the law on the subject. International law has therefore been used as an instrument of persuasion by those who oppose or favor our Viet Nam policy on political grounds. In such a debate we assume that the United States strives to be law-abiding and that, therefore, it is important for partisans of existing policy to demonstrate the compatibility between law and policy and for opponents of the policy to demonstrate the opposite.

This use of international law to bolster or bludgeon foreign policy positions is unfortunate. It creates the impression that international law serves to inflame debate rather than to guide or shape public policy-an impression fostered by the State Department Memorandum. After a decade of fighting in Viet Nam, the Memorandum was issued in response to legal criticisms made by private groups and echoed by a few dissident members of Congress. It blandly whitewashed the existing government position. The tone is self-assured, the method legalistic, and the contribution to an informed understanding of the issues, minimal. None of the difficult questions of legal analysis are considered. In this intellectual context international lawyers with an independent voice need to be heard.

An international lawyer writing about an ongoing war cannot hope to reach clear conclusions about all the legal issues involved. It is virtually impossible to unravel conflicting facts underlying conflicting legal 
claims. Of course, we can hope that a legal commentator will acknowl. edge the uncertainties about the facts and that he will offer explicit reasons for resolving ambiguities in the way and to the extent that he does. ${ }^{125}$

Would it not be better, one is tempted to insist, for international lawyers to avoid so controversial and indeterminate a subject as the legal status of American participation in the war in Viet Nam? I think it important openly to raise this question of propriety, but clearly to answer it in the negative. The scholar has the crucial task of demon* strating the intractability of many, although not of all, the legal issues. Such an undertaking defeats, or calls into serious question, the dogmatic over-clarification of legal issues that arises in the more popular discussions of foreign policy questions. The international lawyer writing in the spirit of scholarly inquiry may have more to contribute by raising the appropriate questions than by purporting to give authoritative answers. He may enable public debate to adopt a more constructive and sophisticated approach to the legal issues.

And, finally, an international lawyer not employed by a government can help modify a distorted nationalistic perspective. An international lawyer is, of course, a citizen with strong views on national policy, but his outlook is universalized by the realization that the function of law in world affairs is to reconcile inconsistent national goals. The international lawyer seeks a legal solution that is based upon an appreciation, although not always an acceptance, of the position of "the other side" in an international dispute. His goal is a system of world order in which all nations are constrained for the common good by rules and by pro. cedures for their interpretation and enforcement. This implies a new kind of patriotism, one that is convinced that to succeed, the nation must act within the law in its foreign as well as its domestic undertakings.

But are there occasions upon which it would be proper for a nation to violate international law? It may be contended that the United States must act as it does in Viet Nam because the international procedures of Geneva, the United Nations, and SEATO offer no protection to a victim of aggression such as South Viet Nam. The United States is acting, in this view, to fill a vacuum created by the failures of inter-

125. Cf. the inscription attributed to "An Old Jew of Galicia" in Milosz, Tue Carrive Mind 2 (1953):

When someone is honestly $55 \%$ right, that's very good and there's no use wrangling. And if someone is $60 \%$ right, it's wonderful, and let him thank God. But what's to be said about $75 \%$ right? Wise people say this is suspicious. Well, and what about $100 \%$ right? Whoever says he's $100 \%$ right is a fanatic, a thug, and the worst kind of rascal. 
national regulatory machinery. In fact, it is often suggested, the refusal of the United States to act would tempt potential aggressors. Those who emphasize the obligations and ambiguities of power often talk in this vein and warn of the sterility of legalism in foreign affairs. ${ }^{120}$ In general terms, this warning is sound, but its very generality is no guide to specific action, especially in the nuclear age. It remains essential to vindicate as explicitly as possible the reasons that might justify violating legal expectations about the use of military power in each instance by documented reference to overriding policies; slogans about peace, security, and freedom are not enough. The analysis must be so conditioned by the specific circumstances that it will not always justify the use of force. I do not believe that such an argument can convincingly be made with respect to Viet Nam, and therefore I affirm the relevance of legal criteria of limitation. If an argument in favor of military intervention is offered, then it should stress the limits and weaknesses of law or the priority of national over international concerns. ${ }^{127}$ We would then gain a better understanding of what law can and cannot do than is acquired by the manipulative straining of legal rules into contrived coincidence wi:h national policies. ${ }^{128}$

\section{V}

The foregoing analysis points to the following set of conclusions:

1) The United States insistence upon treating North Vietnamese assistance to the Vietcong as "an armed attack" justifying recourse to "self-defense" goes a long way toward abolishing the legal significance of the distinction between civil war and international war. Without this distinction, we weaken a principal constraint upon the scope and scale of violence in international affairs-the confinement of violence associated with internal wars to the territory of a single political unit. ${ }^{129}$ Another adverse consequence of permitting "self-defense" in response to covert aggression is to entrust nations with very wide discretion to determine for themselves the occasions upon which recourse to overt

126. See generally the writings of the critical legalists. E.g., KeNNAN, AMrnucax DipLo. MaGY 1900-1950, 95, 96 and 100; MoRgenthau, IN DefeNSE of the National INTEREst (1951).

127. Little systematic attention has been given to the rationale and logic for rejecting the claims of law under certain circumstances in human affairs. The consequence is to lead perceptions into naive over-assertions or cynical denials of the relevance of law to behavior.

128. There is a role for adversary presentation, but there is a more important need to seek bases upon which to appraise adversary claims.

129. One can emphasize the refusal to permit external sanctuary for actors supporting an internal war as a constructive precedent, but its reciprocal operation creates dangers of unrestrained violence. See generally HALPERN, LIATtEd TYAR IN THE N'LCLEAR AGE (1963). 
violence across international boundaries is permissible. ${ }^{130}$ An extension of the doctrine of self-defense would defeat a principal purpose of the United Nations Charter-the delineation of fixed, narrow limits upon the use of overt violence by states in dispute with one another.

2) The United States made no serious attempt to exhaust international remedies prior to recourse to unilateral military power. The gradual unfolding of the conflict provided a long period during which attempts at negotiated settlement could have taken place. Only belatedly and in a pro forma fashion did the United States refer the dispute to the United Nations. The United States made no attempt to comply with "the international law principle" alleged by footnote 10 of the Memorandum to govern the action of North Viet Nam. Nor did it attempt during the early phases of the war to subordinate its discretion to the Geneva machinery. No use was made even of the consultative framework of SEATO, an organization inspired by United States initiative for the specific purpose of inhibiting Communist aggression in Southeast Asia. ${ }^{131}$ Policies of force were unilaterally adopted and put into execution; no account was taken of the procedural devices created to give a collective quality to decisions about the use of force. Yet the prospect for controlling violence in world affairs depends upon the growth of limiting procedural rules and principles.

3) By extending the scope of violence beyond the territory of South Viet Nam the United States has created an unfortunate precedent in international affairs. Where international institutions fail to provide clear guidance as to the character of permissible action, national actions create quasi-legislative precedents. In view of the background of the conflict in Viet Nam (including the expectation that South Viet Nam would be incorporated into a unified Viet Nam under the control of Hanoi after the French departure), the American decision to bomb North Viet Nam sets an unfortunate precedent. If North Viet Nam and its allies had the will and capability to employ equivalent military force, the precedent would even allow them to claim the right to bomb United States territory in reprisal.

4) The widespread domestic instability in the Afro-Asian world points up the need for an approach to internal war that aims above all to insulate this class of conflict from intervention by the great powers. The early use of peace observation forces, border control machinery, restraints on the introduction of foreign military personnel, and standby

130. Cf. Henkin, supra note 70.

131. On the creation of SEATO sẹ SEATO, op. cit. supra notc 107 , introduction, xilixix 
mediation appears possible and beneficial. Responses to allegations of "aggression" should be verified prior to the unilateral use of defensive force, especially when time is available. Claims of covert aggression might then be verified with sufficient authority and speed to mobilize support for community security actions.

5) In the last analysis, powverful nations have a responsibility to use defensive force to frustrate aggression when international machinery is paralyzed. Viet Nam, however, does not provide a good illustration of the proper discharge of this responsibility. North Viet Nam's action does not seem to constitute "aggression." Available international machinery was not used in a proper fashion. The domestic conditions prevailing in South Viet Nam were themselves so inconsistent with prevailing ideals of welfare, progress, and freedom that it is difficult to claim that the society would be better off as a result of a Saigon victory. The massive American presence has proved to be a net detriment, greatly escalating the war, tearing apart the fabric of Vietnamese society, and yet not likely to alter significantly the political outcome. The balance of domestic and area forces seems so favorable to the Vietcong that it is unlikely that the N.L.F. can be kept forever from political control. The sacrifice of lives and property merely postpones what appears to be an inevitable result. The United States voluntarily assumed a political responsibility for the defense of South Viet Nam that has been gradually converted into a political commitment and a self-proclaimed test of our devotion to the concept of collective self-defense. This responsibility is inconsistent with the requirements of world order to the extent that it depends upon unilateral prerogatives to use military power. The national interest of the United States would be better served by the embrace of cosmopolitan isolationism-either we act in conjunction with others or we withdraw. We are the most powerful nation in world history. It is hubris to suppose, however, that we are the policemen of the world. ${ }^{132}$ Our wasted efforts in Viet Nam suggest the futility and frustration of the politics of overcommitment. We are not the only country in the world concerned with containing Communism. If we cannot find cooperative bases for action

132. Even Secretary Rusk has pointed out the limitations upon American power in emphatic terms: "We do not regard ourselves as the policeman of the universe. . . . If other governments, other institutions, or other regional organizations can find solutions to the quarrels which disturb this present scene, we are anxious to have this occur." VIETwAss HearIncs 563; and Secretary MfNamara stated in an address to the American Socicty of Newspaper Editors delivered at Montreal on May 18, 1966: ". . . neither conscience nor sanity itself suggests that the United States is, should, or could be the global gendarme." N.Y. Times, May 19, 1966, p. 11. 
we will dissipate our moral and material energies in a series of Viet Nams. The tragedy of Viet Nam provides an occasion for rethinking the complex problems of use of military power in world affairs and calls for an examination of the increasingly imperial role of the United States in international society. Perhaps we will discover the relevance of international law to the planning and execution of foreign policy as well as to its justification. Certainly the talents of the State Department's Legal Adviser are wasted if he is to be merely an official apologist summoned long after our President has proclaimed "a solemn national commitment." 